\title{
Microbial ecology of the equine hindgut during oligofructose-induced laminitis
}

\author{
Gabriel J Milinovich ${ }^{1}$, Paul C Burrell ${ }^{2}$, Christopher C Pollitt ${ }^{1}$, Athol V Klieve ${ }^{3}$, \\ Linda L Blackall ${ }^{4}$, Diane Ouwerkerk ${ }^{3}$, Erika Woodland ${ }^{1}$ and Darren J Trott ${ }^{1}$ \\ ${ }^{1}$ Australian Equine Laminitis Research Unit, School of Veterinary Science, The University of Queensland, \\ Brisbane, Queensland, Australia; ${ }^{2}$ Biosecurity Sciences Laboratory, Animal Research Institute, Biosecurity \\ Queensland, Brisbane, Queensland, Australia; ${ }^{3}$ Department of Primary Industries and Fisheries, Animal \\ Research Institute, Brisbane, Queensland, Australia and ${ }^{4}$ Advanced Water Management Centre, \\ The University of Queensland, Brisbane, Queensland, Australia
}

\begin{abstract}
Alimentary carbohydrate overload is a significant cause of laminitis in horses and is correlated with drastic shifts in the composition of hindgut microbiota. Equine hindgut streptococcal species (EHSS), predominantly Streptococcus lutetiensis, have been shown to be the most common microorganisms culturable from the equine caecum prior to the onset of laminitis. However, the inherent biases of culture-based methods are estimated to preclude up to $70 \%$ of the normal caecal microbiota. The objective of this study was to evaluate bacterial population shifts occurring in the equine caecum throughout the course of oligofructose-induced laminitis using several cultureindependent techniques and to correlate these with caecal lactate, volatile fatty acid and degrees of polymerization 3-7 fructo-oligosaccharide concentrations. Our data conclusively show that of the total microbiota present in the equine hindgut, the EHSS S. lutetiensis is the predominant microorganism that proliferates prior to the onset of laminitis, utilizing oligofructose to produce large quantities of lactate. Population shifts in lactobacilli and Escherichia coli subpopulations occur secondarily to the EHSS population shifts, thus confirming that lactobacilli and coliforms have no role in laminitis. A large, curved, Gram-negative rod previously observed during the early phases of laminitis induction was most closely related to the Anaerovibrio genus and most likely represents a new, yet to be cultured, genus and species. Correlation of fluorescence in situ hybridization and quantitative real-time PCR results provide evidence supporting the hypothesis that laminitis is associated with the death en masse and rapid cell lysis of EHSS. If EHSS are lysed, liberated cellular components may initiate laminitis.
\end{abstract}

The ISME Journal (2008) 2, 1089-1100; doi:10.1038/ismej.2008.67; published online 26 June 2008

Subject Category: microbe-microbe and microbe-host interactions

Keywords: laminitis; oligofructose; streptococci; hindgut

\section{Introduction}

Laminitis constitutes the most serious condition of the equine foot, representing between $7.5 \%$ and $15.7 \%$ of all lameness problems (USDA, 2000). In the horse, laminitis results in basement membrane damage and eventual lamellar separation at the dermal-epidermal junction (French and Pollitt, 2004). This lamellar instability results in detachment of the distal phalanx from the inner hoof wall and, in severe cases, downward displacement and rotation of the bone. Under the animal's weight this damages the vasculature of the hoof, crushes the corium of the

Correspondence: GJ Milinovich, Australian Equine Laminitis Research Unit, School of Veterinary Science, The University of Queensland, Building 82, Slip Road, St Lucia, Brisbane, Queensland 4072, Australia.

E-mail: g.milinovich@uq.edu.au

Received 1 April 2008; revised 4 June 2008; accepted 5 June 2008; published online 26 June 2008 sole and coronet, often necessitating euthanasia (Pollitt, 1999). The specific mechanisms by which lamellar separation occurs remain to be elucidated; however, the factors responsible for initiating laminitis are well described, the most common being carbohydrate overload through exposure to certain pastures or excess grain (USDA, 2000).

Consumption of pasture has been reported to account for in excess of $45 \%$ of laminitis cases (USDA, 2000). In some plants, most notably temperate grasses, fructans ( $\beta$-D-fructose polymers with terminal glucose monomers) constitute the predominant form of storage carbohydrate (Roberfroid and Delzenne, 1998). Under certain climatic conditions, starch may account for as little as $10-13 \%$ of the total stored carbohydrate in these species, the remainder being sucrose and fructans (Cairns and Longland, 1998). Mammals are unable to metabolize fructans (Nilsson et al., 1988) and in the equid, the fructans in grasses are rapidly transported through 
the stomach and small intestine to the caecum and colon where microbial digestion occurs. The introduction of high levels of fructans results in largescale changes in the composition of the hindgut microbiota. Using an oligofructose-induction model (van Eps and Pollitt, 2006), we demonstrated a rapid proliferation of oligofructose-utilizing streptococci of the Streptococcus bovis/equinus complex immediately prior to the onset of laminitis. This was followed by an equally rapid decline in streptococci as lactobacilli and Enterobacteriaceae became more predominant in the post-laminitis period (Milinovich et al., 2006, 2007). These changes mirrored a drop in caecal $\mathrm{pH}$ from between 6.2 and $6.8-4.5$ or below. However, these studies were either culturebased (Milinovich et al., 2006) or included large culture-dependant elements (Milinovich et al., 2007) and have to be tempered by the knowledge that only $30 \%$ of the equine caecum microbiota can be cultivated (Mackie and Wilkins, 1988).

The purpose of the current study was to identify and quantify the key bacterial species in the equine caecum during oligofructose-induced laminitis using a culture-independent approach and to correlate the changes in the major groups of microorganisms with substrates and end products detectable in caecal fluid. Laminitis was induced by nasogastric administration of a bolus dose of oligofructose in five horses fitted with caecal cannulae (van Eps and Pollitt, 2006; Milinovich et al., 2007). Caecal fluid samples collected over a $36 \mathrm{~h}$ period were assayed by denaturing gradient gel electrophoresis (DGGE) of PCR amplified V2/V3 variable regions of 16S rRNA genes. Quantitative real-time PCR (qPCR) of the 16S rRNA genes of selected microorganisms further characterized the DGGE-determined microbial community. Microbial changes established by these latter methods were compared with changes in caecal fluid lactate, volatile fatty acid (VFA) and concentrations of fructo-oligosaccharide with degrees of polymerization (DP) of 3-7.

\section{Materials and methods}

Laminitis induction, sample collection and processing This project was approved by The University of Queensland Animal Ethics Committee (SVS/727/ 04). All animals were continuously monitored by the investigators and the horses were inspected by the Consultant Veterinary Officer to the Animal Welfare Unit at the University of Queensland at the request of the Animal Ethics Committee. If pain could not be alleviated promptly, early euthanasia, even if this was prior to the planned conclusion of the experiment, was a proviso of the protocol.

Details of the five horses (1-5) fitted with cannulae into surgically placed caecal fistulas have been provided in previous publications (Croser and Pollitt, 2006; Milinovich et al., 2007). Laminitis induction was achieved by administration of
$10 \mathrm{~g} \mathrm{~kg}^{-1}$ body weight of oligofructose (Raftilose P95, Orafti Active Food Ingredients, Tienen, Belgium) by a nasogastric tube (van Eps and Pollitt, 2006).

Caecal fluid specimens were collected through the caecal cannulae at $2 \mathrm{~h}$ intervals in the $0-24 \mathrm{~h}$ postoligofructose administration (POA) period and at $4 \mathrm{~h}$ intervals in the 24-36 h POA period. Specimens were immediately fixed in both $98 \%$ ethanol and $4 \%$ paraformaldehyde for fluorescence in situ hybridization (FISH; Amann, 1995) and frozen at $-80^{\circ} \mathrm{C}$ for DGGE, qPCR and determination of lactate, VFA and individual (DP3-7) fructo-oligosaccharide concentrations. Additionally, six serial hoof biopsies were collected from each horse at $0,12,18,24$, 30 and $36 \mathrm{~h}$ POA to monitor histopathological changes consistent with the onset of laminitis (Croser and Pollitt, 2006).

DNA extraction procedure

Caecal fluid samples stored at $-80{ }^{\circ} \mathrm{C}$ were available for all time points except 14 and $28 \mathrm{~h}$ POA from horse 2. DNA for use in DGGE and qPCR was extracted from $1 \mathrm{~g}$ (samples $0 \mathrm{~h}$ POA from horses 2,4 and 5 and samples $0,20,28,32$ and $36 \mathrm{~h}$ from horse 1) or $1 \mathrm{ml}$ (all other samples) of caecal fluid by the repeated bead-beating, column extraction method (Yu and Forster, 2005) and eluted to a final volume of $500 \mu \mathrm{l}$. Samples of $1 \mathrm{~g}$ were used when the water content was too low to measure the sample volumetrically.

\section{PCR amplification and denaturing gradient gel electrophoresis}

PCRs used extracted DNA as templates and the 341fGC (5'-CGCCCGCCGCGCGCGGCGGGCGGGGCGGG GGCACGGGGGGCCTACGGGAGGCAGCAG-3') and 534r (5'-ATTACCGCGGCTGCTGG-3') bacterial primers and cycling conditions of the authors (Muyzer et al., 1993) to amplify the variable V2/V3 region of bacterial 16S rRNA genes. All PCRs for DGGE used Red Hot DNA polymerase (Thermo Fisher Scientific, Waltham, MA, USA) according to the manufacturer's instructions. Amplicons were separated by DGGE (DCode System; Bio-Rad, Hercules, CA, USA) on $8 \%$ acrylamide gels with $30-60 \%$ formamide/ urea gradients. All gels were run at $100 \mathrm{~V}$ and $60^{\circ} \mathrm{C}$ over $18 \mathrm{~h}$ in $0.5 \times$ TAE buffer (Tris-acetate, $0.04 \mathrm{M}$; EDTA, $0.001 \mathrm{M})$. A reference ladder of Klieve et al. (2007), consisting of amplicons from isolates with various melting profiles spanning the length of the gel, was run on all gels. DNA bands were visualized following electrophoresis by silver staining (Kocherginskaya et al., 2005).

\section{Clone library preparation}

Near full-length $16 \mathrm{~S}$ rRNA gene clone libraries were produced from the 0,10 and $28 \mathrm{~h}$ POA samples from 
horses 1 and 4. The 16S rRNA genes were amplified using the universal bacterial primers $27 f\left(5^{\prime}\right.$-AGA GTTTGATCMTGGCTCAG-3') and 1525r (5'-AAGG AGGTGWTCCARCC-3'; Lane, 1991) according to previously reported cycle parameters (Ouwerkerk and Klieve, 2001). All PCRs used Red Hot DNA polymerase (Thermo Fisher Scientific) according to the manufacturer's instructions. Amplificates were cloned using the Topo TA cloning kit (Invitrogen, Carlsbad, CA, USA) and the manufacturer's instructions. The inserts from 16 clones, from each library, were analysed by DGGE as described above.

\section{DGGE band identification}

Five additional DGGE ladders were prepared by PCR, using the $341 \mathrm{f}-\mathrm{GC}$ and $534 \mathrm{r}$ primers, from previously isolated equine hindgut microorganisms (Milinovich et al., 2006, 2008) and clones produced in this study. Ladder 1 included the equine hindgut streptococcal species (EHSS) isolates and clones and the Escherichia coli clones and isolates, ladder 2 Lactobacillus isolates and clones, ladder 3 Anaerovibrio-like and Succinivibrio dextrinosolvens-like clones, ladder 4 previously isolated Enterococcus isolates and Clostridium-like clones and ladder 5 other miscellaneous clones including Actinobacillus rossii, Eubacterium rectale and uncultured microorganisms most closely related to Anaerostipes spp., Subdoligranulum spp., $\gamma$-Proteobacteria and Lachnospiraceae. DGGE was subsequently performed on all caecal fluid samples, as described above, against each of the five ladders allowing presumptive identification of banding patterns of interest.

DNA sequencing and analysis

The inserts of representative clones from each DGGE banding pattern were amplified with $27 \mathrm{f}$ and $1525 \mathrm{r}$.
Amplificates were purified with the QIAquick PCR purification kit (Qiagen, Hilden, Germany) and sequenced with primers 27f, 1525r, 907r (Lane, 1991) and 803f (Lane, 1991) using a BigDye Terminator (version 3.1) sequencing kit (Applied Biosystems, Foster City, CA, USA). Phylogenetic analyses of $16 \mathrm{~S}$ rRNA genes were carried out as previously described (Bjornsson et al., 2002).

\section{Quantitative real-time PCR}

qPCR assays were used to enumerate bacterial populations of interest as identified by DGGE. All Taq nuclease assays used RealMasterMix Probe kits (Eppendorf, Hamburg, Germany), SYBR green assays used the SYBR GreenER qPCR SuperMix Universal kit (Invitrogen) and the kit manufacturer's instructions. qPCR primer sets (Table 1) targeting the $16 \mathrm{~S}$ rRNA genes were used at a final concentration of $900 \mathrm{nM}$. All qPCRs were $25 \mu \mathrm{l}$ and used $5 \mu \mathrm{l}$ DNA extracted from caecal fluid (described above) diluted $10^{-1}$, as templates. The Anaerovibrio lipolyticus (Tajima et al., 2001), Enterobacteriaceae (Bartosch et al., 2004), S. bovis (Klieve et al., 2003) and S. dextrinosolvens (Stevenson and Weimer, 2007) qPCR assays used the methods in the publications.

The bacterial assay described by Nadkarni et al. (2002) was modified to include a minor groove binder moiety into the probe. This shortened the probe by 10 nucleotides at the $5^{\prime}$ end without affecting the $T_{\mathrm{M}}$ and increased the coverage of the probe for bacterial $16 \mathrm{~S}$ rRNA genes. The original probe (Nadkarni et al., 2002) was identical in sequence to $61.5 \%$ of bacterial 16S rRNA sequences in the Ribosomal Database Project (RDP) database, whereas the redesigned probe was identical to $75.9 \%$ of RDP database sequences. The cycle parameters for this assay were modified to: an initial step at $94{ }^{\circ} \mathrm{C}$ for $1 \mathrm{~min}$, then 40 cycles of $94{ }^{\circ} \mathrm{C}$ for $10 \mathrm{~s}$ and $60{ }^{\circ} \mathrm{C}$ for $10 \mathrm{~s}$.

Table 1 qPCR probes and primers used in this study

\begin{tabular}{|c|c|c|c|c|c|c|}
\hline $\begin{array}{l}\text { Bacterial group } \\
\text { targeted }\end{array}$ & Assay type & $\begin{array}{l}\text { Amplicon } \\
\text { size (bp) }\end{array}$ & $\begin{array}{l}\text { Forward primer } \\
\left(5^{\prime}-3^{\prime}\right)\end{array}$ & Reverse primer (5'-3') & Probe $\left(5^{\prime}-3^{\prime}\right)$ & References \\
\hline All Bacteria & $\begin{array}{l}\text { Taq } \\
\text { nuclease }\end{array}$ & 466 & $\begin{array}{l}\text { TCCTACGGGAGG } \\
\text { CAGCAGT }\end{array}$ & $\begin{array}{l}\text { GGACTACCAGGGTA } \\
\text { TCTAATCCTGTT }\end{array}$ & $\begin{array}{l}\text { 6FAM-CGGCTGCTGGCAC- } \\
\text { MGBBHQ }\end{array}$ & \multirow{2}{*}{$\begin{array}{l}\text { Modification of } \\
\text { bacterial assay } \\
\text { (Nadkarni et al., 2002) } \\
\text { (Klieve et al., 2003) }\end{array}$} \\
\hline Streptococcus bovis & $\begin{array}{l}\text { Taq } \\
\text { nuclease }\end{array}$ & 90 & $\begin{array}{l}\text { ATGTTAGATGCTTGA } \\
\text { AAGGAGCAA }\end{array}$ & $\begin{array}{l}\text { CGCCTTGGTGAGC } \\
\text { CGTTA }\end{array}$ & $\begin{array}{l}\text { 6FAM-CTCACCAACT } \\
\text { AGCTAATACA } \\
\text { ACGCAGGTCCA-TAMRA }\end{array}$ & \\
\hline $\begin{array}{l}\text { Equine hindgut } \\
\text { streptococcal species } \\
\text { (excluding } \\
\text { Streptococcus } \\
\text { gallolyticus) }\end{array}$ & $\begin{array}{l}\text { Taq } \\
\text { nuclease }\end{array}$ & 127 & $\begin{array}{l}\text { GAAACGATAGCTAA } \\
\text { TACCGCATAA }\end{array}$ & $\begin{array}{l}\text { CGCCTTGGTGAGC } \\
\text { CKTTA }\end{array}$ & $\begin{array}{l}\text { 6FAM-CTCACCAACTAG } \\
\text { CTAATACAACGCAGG } \\
\text { TCCA-TAMRA }\end{array}$ & $\begin{array}{l}\text { Modification of } S \text {. bovis } \\
\text { asssay (Klieve et al., } \\
\text { 2003) }\end{array}$ \\
\hline Enterobacteriaceae & $\begin{array}{l}\text { SYBR } \\
\text { green }\end{array}$ & 195 & $\begin{array}{l}\text { AGCAGTAGGGAAT } \\
\text { CTTCCA }\end{array}$ & $\begin{array}{l}\text { ATTYCACCGCTA } \\
\text { CACATG }\end{array}$ & Not applicable & (Bartosch et al., 2004) \\
\hline $\begin{array}{l}\text { Succinivibrio } \\
\text { dextrinosolvens }\end{array}$ & $\begin{array}{l}\text { SYBR } \\
\text { green }\end{array}$ & 73 & $\begin{array}{l}\text { CGTCAGCTCGTGTC } \\
\text { GTGAGA }\end{array}$ & $\begin{array}{l}\text { CCCGCTGGCAAC } \\
\text { AAAGG }\end{array}$ & Not applicable & $\begin{array}{l}\text { (Stevenson and Weimer, } \\
\text { 2007) }\end{array}$ \\
\hline $\begin{array}{l}\text { Anaerovibrio } \\
\text { lipolyticus }\end{array}$ & $\begin{array}{l}\text { SYBR } \\
\text { green }\end{array}$ & 597 & $\begin{array}{l}\text { TGGGTGTTAGAA } \\
\text { ATGGATTC }\end{array}$ & $\begin{array}{l}\text { CTCTCCTGCACTCA } \\
\text { AGAATT }\end{array}$ & Not applicable & (Tajima et al., 2001) \\
\hline $\begin{array}{l}\text { Anaerovibrio and } \\
\text { Anaerovibrio-like } \\
\text { clones }\end{array}$ & $\begin{array}{l}\text { SYBR } \\
\text { green }\end{array}$ & 169 & $\begin{array}{l}\text { CTCACAGGAGA } \\
\text { CTGCCGC }\end{array}$ & $\begin{array}{l}\text { AGCCTGCAATCCG } \\
\text { AACTG }\end{array}$ & Not applicable & This study \\
\hline
\end{tabular}


The $S$. bovis qPCR assay of Klieve et al. (2003) was modified to target all previously isolated EHSS, with the exception of Streptococcus gallolyticus subsp. gallolyticus, $S$. gallolyticus subsp. macedonicus, Streptococcus henryi and Streptococcus caballi (Milinovich et al., 2006, 2008) and all streptococcal clones with the exception of one clone (H1-28-16). According to BLAST, this clone was most closely related to $S$. gallolyticus subsp. macedonicus (1469 nt; 96\%). The modified assay did not target any non-streptococcal isolates or clones. The cycle parameters for this assay were identical to the $S$. bovis qPCR assay (Klieve et al., 2003).

The A. lipolyticus qPCR assay (Tajima et al., 2001) did not target the Anaerovibrio-like clones produced by this study. Therefore, an assay for Anaerovibrio and similar clones, but no organisms outside the Anaerovibrio genus was designed. The cycle parameters for this assay were: an initial step at $95^{\circ} \mathrm{C}$ for $10 \mathrm{~min}$, then 45 cycles of $95^{\circ} \mathrm{C}$ for $15 \mathrm{~s}$ and $60^{\circ} \mathrm{C}$ for $60 \mathrm{~s}$.

Standards for qPCR were produced using E. coli (ATCC 25922), S. bovis (isolate AR3; Klieve et al., 1989), A. lipolyticus (DSM 3074) and S. dextrinosolvens (DSM 3072). Briefly, cell counts from overnight cultures were conducted (Ouwerkerk et al., 2002) and concentrations adjusted to $10^{10}$ cells per ml. DNA was extracted (described above) from $1 \mathrm{ml}$ of each 10-fold serial dilution from $10^{10}$ through to $10^{3}$ cells per ml. Standards of $5 \mu \mathrm{l}$, diluted $10^{-1}$, were used as templates in all qPCR assays to allow copy numbers of the targeted genes to be converted to cell numbers. E. coli (ATCC 25922) was used as a standard for the total bacteria assay.

\section{Oligonucleotide probe design and optimization}

The FISH probes Succ654 (targeting S. dextrinosolvens and $S$. dextrinosolvens-like clones) and Ana1141 (targeting A. lipolyticus and similar clones) were designed using previously published methods (Hugenholtz et al., 2001, 2002). All probes (Table 2) were synthesized and labelled at the $5^{\prime}$ end with the sulfoindocyanine dyes Cy3, Cy5 or fluorescein isothiocyanate (FITC; Thermo Electron Corporation, Ulm, Germany). The optimum formamide concentrations (Table 2) were determined for FISH using a positive (bacteria with 100\% sequence identity) and a negative (bacteria with a one base mismatch, where available) control sourced from previous equine laminitis experiments ( $\mathrm{Al}$ Jassim et al., 2005; Milinovich et al., 2006) or type-culture collections. The optimum formamide concentration was determined for each probe by carrying out FISH at $0 \%, 10 \%, 20 \%, 30 \%, 40 \%$ and $50 \%$ formamide. All probe hybridizations were conducted at $46^{\circ} \mathrm{C}$.

\section{Fluorescence in situ hybridization}

Fluorescence in situ hybridization used CY3-labelled group-specific probes (Table 2) and FITClabelled EUBMIX with all fixed samples except 2 and $28 \mathrm{~h}$ POA from horses 1 and 2, respectively. An Olympus BX50 microscope with an Olympus BX-FLA reflected light fluorescence attachment (Olympus Optical Co., Ltd, Japan), a × 1001.30 NA UPlanFl oil-immersion objective and U-MF and U-MWG filters were used to visualize FISH-probed samples. The relative abundance of the bacteria was determined by a previously reported subjective scoring method (Milinovich et al., 2007). Subjective scores were: $0 \%$, occasional presence (fewer than one microorganism per field of vision and not possible to quantify), $<1 \%, 1-5 \%, 6-10 \%$ and then $10 \%$ increments up to $91-100 \%$.

Lactate, volatile fatty acid and fructo-oligosaccharide analyses

Lactate, VFA and DP3-7 fructo-oligosaccharide concentrations were determined in caecal fluid

Table 2 Fluorescence in situ hybridisation oligonucleotides used in this study

\begin{tabular}{|c|c|c|c|c|c|c|c|}
\hline Probe & Probe sequence & $\begin{array}{l}16 S \text { rRNA } \\
\text { target site }\end{array}$ & Specificity & $\underset{\%}{\text { Formamide }}$ & $\begin{array}{l}\text { Positive } \\
\text { control }\end{array}$ & $\begin{array}{l}\text { Negative } \\
\text { control }\end{array}$ & References \\
\hline EUB338 $^{\mathrm{a}}$ & GCTGCCTCCCGTAGGAGT & $338-355$ & Most but not all bacteria & $0-50$ & NA & NA & $\begin{array}{l}\text { (Stahl and Amann, } \\
\text { 1991) }\end{array}$ \\
\hline EUB338-II ${ }^{\mathrm{a}}$ & GCAGCCACCCGTAGGTGT & $338-355$ & $\begin{array}{l}\text { Bacterial groups not } \\
\text { covered by EUB338 and } \\
\text { EUB338-III }\end{array}$ & $0-50$ & NA & NA & (Daims et al., 1999) \\
\hline EUB338-III ${ }^{\mathrm{a}}$ & GCTGCCACCCGTAGGTGT & $338-355$ & $\begin{array}{l}\text { Bacterial groups not } \\
\text { covered by EUB338 and } \\
\text { EUB338-II }\end{array}$ & $0-50$ & NA & NA & (Daims et al., 1999) \\
\hline Ana1141 & $\begin{array}{l}\text { CGCGGCAGTCTCCTGTGA } \\
\text { GTTCCCA }\end{array}$ & 1141-1165 & $\begin{array}{l}\text { Anaerovibrio lipolyticus } \\
\text { and Anaerovibrio-like } \\
\text { clones }\end{array}$ & 50 & $\begin{array}{l}\text { Anaerovibri } \\
\text { lipolyticus } \\
\text { (DSM3074) }\end{array}$ & $\begin{array}{l}\text { Mitsuokella } \\
\text { jalaludinii } \\
\text { (RA2107) }^{\mathrm{b}}\end{array}$ & This study \\
\hline Succ654 & TCTCCCCCTGCAATACTC & $654-671$ & $\begin{array}{l}\text { Succinivibrio } \\
\text { dextrinosolvens and } \\
\text { similar clones }\end{array}$ & 20 & $\begin{array}{l}\text { Succinivibrio } \\
\text { dextrinosolvens } \\
\text { (DSM3072) }\end{array}$ & $\begin{array}{l}\text { Rhodococcus } \\
\text { equi }(\mathrm{B} 06 / 0148)^{\mathrm{c}}\end{array}$ & This study \\
\hline
\end{tabular}

Abbreviation: NA, not applicable.

${ }^{a}$ EUBMIX was equal amounts of EUB338, EUB338-II and EUB338-III.

bisolate from a previous equine laminitis trial (Al Jassim et al., 2005).

cClinical isolate from The University of Queensland Veterinary Diagnostic Bacteriology Laboratory. 
samples. High performance liquid chromatography (HPLC) was used to analyse for lactate and fructooligosaccharide and gas chromatography was used for VFAs. Briefly, $4 \mathrm{ml}$ of caecal fluid was mixed with $1 \mathrm{ml}$ of $6 \%$ phosphoric acid and centrifuged at $16{ }^{\circ} \mathrm{C}$ for $10 \mathrm{~min}$ at $1000 \mathrm{~g}$. The supernatant of samples for lactate and VFA analysis was passed through a $300 \mathrm{mg} \mathrm{C-18} \mathrm{Sep} \mathrm{Pak} \mathrm{(Alltech} \mathrm{Associates,}$ Deerfield, IL, USA) and a $0.45 \mu \mathrm{m}$ filter and stored at $4{ }^{\circ} \mathrm{C}$ prior to analysis. The supernatant of samples for fructo-oligosaccharide analysis were passed through a GF/B glass fibre filter (Whatman, Maidstone, UK), through $500 \mathrm{mg}$ of Dowex $50 \times 8\left(\mathrm{H}^{+}\right.$form; SigmaAldrich Co., Buchs, Switzerland) coupled to a $300 \mathrm{mg}$ C-18 Sep Pak (Alltech) and a $0.45 \mu \mathrm{m}$ filter and stored at $4{ }^{\circ} \mathrm{C}$ prior to analysis.

Lactate was determined on an Agilent 1100 HPLC (Agilent Technologies, Palo Alto, CA, USA) by the method of Ewaschuk et al. (2002). Samples were passed through a Prevail Organic Acid $5 \mathrm{u}$ $250 \times 4.6 \mathrm{~mm}$ column (Alltech) at a flow rate of $1.0 \mathrm{ml} \mathrm{min}^{-1}$. Mobile phases $\mathrm{A}$ and $\mathrm{B}$ were $25 \mathrm{mM}$ $\mathrm{K}_{2} \mathrm{HPO}_{4}$ ( $\mathrm{pH} 2.5$ ) and methanol, respectively. The column was equilibrated in $100 \%$ mobile phase A and the gradient was $0-4 \min 100 \%$ A, 4-10 min linear gradient to $10 \% \mathrm{~B}, 10-12$ min linear gradient to $25 \% \mathrm{~B}, 12-24 \mathrm{~min} 25 \% \mathrm{~B}, 14-18 \mathrm{~min}$ linear gradient to $100 \% \mathrm{~A}$ and $18-25 \mathrm{~min} 100 \% \mathrm{~A}$. Detection was with a ultraviolet detector at $210 \mathrm{~nm}$ calibrated with 50, 100, 200 and $300 \mu \mathrm{g} \mathrm{ml}^{-1}$ lactate standards prepared from lithium lactate.

VFAs were determined with a Shimadzu GC-17A gas chromatograph (Shimadzu Corporation, Kyoto, Japan) fitted with a splitless injection port glass liner (SGE Analytical Science, Austin, TX, USA) and a capillary column (DB-FFAP $30 \mathrm{~m} \times 0.53 \mathrm{~mm} \times$ $1.0 \mu \mathrm{m}$ column; J\&W Scientific, Folsom, USA) with the pre-column end attached to the injection port and a flame ionization detector. The oven temperature was initially set to $110^{\circ} \mathrm{C}$ for $4 \mathrm{~min}$ and increased to $200{ }^{\circ} \mathrm{C}$ at a rate of $15^{\circ} \mathrm{C}$ per min. The injector and detector temperatures were 220 and $225^{\circ} \mathrm{C}$, respectively, and high purity helium was used as the carrier gas at a column head pressure of $35 \mathrm{kPa}$. A multi-acid standard containing $35.1 \mathrm{mM}$ acetate, $8.1 \mathrm{mM}$ propionate, $4.0 \mathrm{mM}$ isobutyrate, $5.1 \mathrm{~mm}$ n-butyrate, $3.0 \mathrm{~mm}$ isovalerate and $3.1 \mathrm{~mm}$ valerate was made and prepared with $6 \%$ phosphoric acid as described above for caecal fluid.

For fructo-oligosaccharides, an Agilent 1100 HPLC fitted with a Prevail Carbohydrate ES 5u $250 \times 4.6 \mathrm{~mm}$ column (Alltech) was used with a flow rate of $1.0 \mathrm{ml} \mathrm{min}^{-1}$. Mobile phases A and $\mathrm{B}$ were acetonitrile and Milli-Q deionized water, respectively. The column was equilibrated in $90 \% \mathrm{~A}$ and $10 \% \mathrm{~B}$ and the gradient was $0-5 \mathrm{~min}, 10-25 \% \mathrm{~B}$; 5-20 min linear gradient, $25-45 \% \mathrm{~B} ; 20-22 \mathrm{~min}$, $45 \% \mathrm{~B} ; 22-25$ min linear gradient to $10 \% \mathrm{~B}$ and $25-$ 30 min $10 \%$ B. Detection was by an Alltec ELSD 2000 detector. Calibration of the ELSD detector was with raffinose at $1.0,2.0,5.0$ and $10.0 \mathrm{mg} \mathrm{ml}^{-1}$.
Retention times for fructo-oligosaccharides of interest were determined by running a $10.0 \mathrm{mg} \mathrm{ml}^{-1}$ oligofructose (Raftilose P95; Orafti Active Food Ingredients) standard.

\section{Results}

Induction of laminitis

As previously reported (Croser and Pollitt, 2006; Milinovich et al., 2007), all horses exhibited depressed appetite by $8 \mathrm{~h}$ POA and developed profuse, watery diarrhoea by $16 \mathrm{~h}$ POA. All five horses developed acute caecal acidosis with $\mathrm{pH}$ dropping from $6.2-6.8$ to below 5 by $6-12 \mathrm{~h}$ POA and all caecal fluid samples collected between 2 and $24 \mathrm{~h}$ POA had $\mathrm{pH}$ values significantly lower than the time zero value $(P<0.05$; Milinovich et al., 2007). Laminitis was diagnosed clinically by the onset of lameness, characteristic of laminitis, in all horses (van Eps and Pollitt, 2004). Clinical laminitis was initially observed in horses 1,4 and 5 at $20-28 \mathrm{~h}$ POA and at 38 and $43 \mathrm{~h}$ POA in horses 2 and 3 , respectively. Histological changes within the foot, notably rounded lamellar epidermal cell nuclei and attenuation of secondary epidermal lamellae, that signal laminitis onset, were first observed at $12 \mathrm{~h} \mathrm{POA}$ in horses 1 and 4, $18 \mathrm{~h} \mathrm{POA}$ in horse 5 and $30 \mathrm{~h}$ POA in horses 2 and 3 (Croser and Pollitt, 2006).

Denaturing gradient gel electrophoresis and $16 S$ rRNA gene sequencing

DGGE identified a number of trends in caecal bacterial population shifts, occurring throughout the laminitis process, between the five horses. Over the time course, microorganisms represented by amplicons occupying positions towards the bottom of the gel decreased, whereas those represented by bands positioned towards the top of the gel increased (Figure 1, Supplementary Figures 1-5).

Equine hindgut streptococcal species. All EHSS clones $(n=12)$ and isolates collected from previous studies $(n=100)$ formed a single band by DGGE with the exception of $S$. henryi and $S$. caballi (which together formed one band) and one clone from horse 4 (clone H4-10-15). According to near full-length (>1460 nt) 16S rRNA gene sequence identity, 11 of the 12 EHSS clones were closest to Streptococcus lutetiensis (AB362710; 99.7-99.8\% $(n=6)$, AF104109; 94.8-95\% $(n=2)$, AY442813; 99.2-99.6\% $(n=2), \quad$ EB163444; $97.5 \% \quad(n=1))$ and one to S. gallolyticus subsp. macedonicus (AF459413; $96.9 \%$ ). The clone that formed a unique banding pattern (H4-10-15) was most closely related to S. lutetiensis (AB362710; 99.8\%). The clone most closely related to $S$. gallolyticus subsp. macedonicus grouped with the other EHSS. Banding patterns characteristic of $S$. henryi and $S$. caballi and of clone H4-10-15 were only observed at low intensity in 
1094

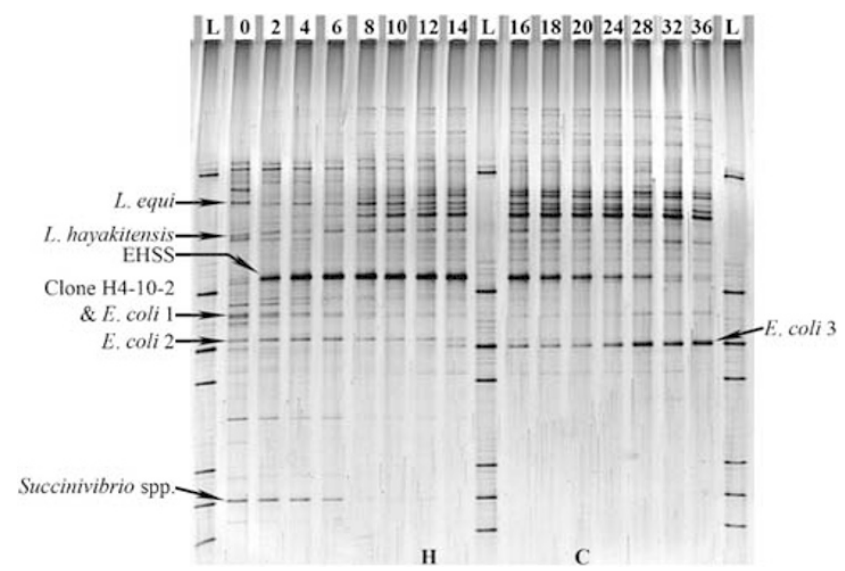

Figure 1 Denaturing gradient gel electrophoresis of the PCR amplified V2/V3 region of 16S rRNA genes from the caecal fluid of horse 4. Numbers at the top of the gel indicate time, in hours post-oligofructose administration (POA), and $\mathrm{L}=$ ladder. Horse 4 initially exhibited histological evidence of laminitis $(\mathrm{H})$ at $12 \mathrm{~h}$ POA and clinical signs of laminitis (C) at $20 \mathrm{~h}$ POA. The microorganisms listed on the left- and right-hand sides of the gel represent the most commonly observed microorganisms from all five horses assayed. Note: BLAST analysis of near full-length $16 \mathrm{~S}$ rRNA gene sequence data of clone H4-10-2 indicated that this most closely related to Anaerovibrio lipolyticus (AB034191: 93.2\%).

horses 5 and 4, respectively. The main EHSS band demonstrated a marked and extremely rapid increase in intensity $2-4 \mathrm{~h}$ POA (Figure 1 ) in all horses except horse 2. EHSS of horse 2 initially decreased slightly in intensity before increasing at $16 \mathrm{~h}$ POA. The EHSS band was observed at all time points.

Escherichia coli. DGGE of the variable V2/V3 region of the $16 \mathrm{~S}$ rRNA gene demonstrated a clear and consistent shift in the equine hindgut $E$. coli subpopulations throughout the laminitis process. $E$. coli was found to be represented by two separate bands, in all horses, at the $0 \mathrm{~h}$ time point (Figure 1; E. coli 1 and 2). These two bands decreased in intensity in all five horses and were not observable in four of the five horses by the final time point analysed at $36 \mathrm{~h}$ POA. A third banding pattern, $E$. coli 3, became the most intense of the E. coli bands between 16 and $24 \mathrm{~h}$ POA in all five horses (Figure 1).

Anaerovibrio. A clone (clone H4-10-2), most closely related to A. lipolyticus (AB034191: 93.2\%), occupied the same position on the DGGE gel as E. coli 1 (Figure 1). Therefore, qPCR and FISH analyses for this microorganism were used to further assess its abundance throughout the laminitis process. Different Anaerovibrio-like clones, which formed a second band towards the top of the gel, were observed in two of the five horses.

Succinivibrio. One clone from horse 4 (clone H4-0-8) had highest identity to $S$. dextrinosolvens (Y17600: $96.4 \%)$. A DGGE band at the same position as this microorganism was observed, to varying degrees, in all five horses (Figure 1). This band was typically observed at low to moderate intensity at $0 \mathrm{~h}$ POA and intensified slightly between 2 and $8 \mathrm{~h}$ POA before becoming non-detectable by $14-20 \mathrm{~h}$ POA in horses 1 , 3,4 and 5 and by $32 \mathrm{~h}$ in horse 2 . The band was most prominent in horse 2 , where it peaked in intensity at $6 \mathrm{~h}$ POA. Conversely, horse 1 exhibited this band at only very light intensity throughout the laminitis process.

Lactobacilli. The lactobacilli ladder produced in this study (ladder 2) contained lactobacilli isolates and clones which generated eight separate DGGE bands. Of these, only two bands were found to be common in all five horses. According to BLAST of near full-length $16 \mathrm{~S}$ rRNA gene sequences ( $>1455 \mathrm{nt}$ ) the clones that formed these bands had the highest identity with Lactobacillus equi (AB048833: 99.4\%) and Lactobacillus hayakitensis (AB267406: 99.7\%), which are considered to be commensals of the equine gastrointestinal tract (Morotomi et al., 2002; Morita et al., 2007). Intensification of the lactobacilli bands was not as marked as for other species, such as the EHSS and E. coli 3, and appeared to be secondary to EHSS proliferation (Figure 1).

Other bacteria. None of the bands from bacterial species in DGGE ladder 5 were consistently observed across the five horses. These microorganisms were, therefore, not considered to be of interest with regard to laminitis, and were not investigated further. Furthermore, no other banding patterns, other than those identified and previously discussed, were observed consistently across all five horses.

\section{Quantitative real-time PCR}

Equine hindgut streptococcal species. All qPCR data are supplied in Supplementary Table 1. qPCR results for the total bacteria and the EHSS assay (modified from the $S$. bovis qPCR assay of Klieve et al. (2003) to target a wider range of streptococci found in the equine hindgut) are shown in Figure 2. Enumerations of EHSS were, on average, 11 times higher by the modified assay than by the original $S$. bovis assay (data not shown). The EHSS qPCR results correlated with the FISH quantification results with probe Sb127, previously reported for these samples (Figure 2; Milinovich et al., 2007). EHSS constituted $\geqslant 80 \%$ of all bacteria, by qPCR, in three of the five horses prior to the onset of histological signs of laminitis (horses 3-5) and for horses 1 and 2 , peaked at $33.0 \%$ and $19.1 \%$, respectively. Proportionally, EHSS returned to, or close to, the pre-induction values by $36 \mathrm{~h} \mathrm{POA}$ in four of the five horses. However, EHSS qPCR copy numbers never resumed their pre-induction values, but remained elevated (Figure 2).

Enterobacteriaceae. The Enterobacteriaceae qPCR results were consistent with previously reported 
FISH results using the Ent probe (specific for Enterobacteriaceae; Milinovich et al., 2007). Enterobacteriaceae increased in all horses; this increase
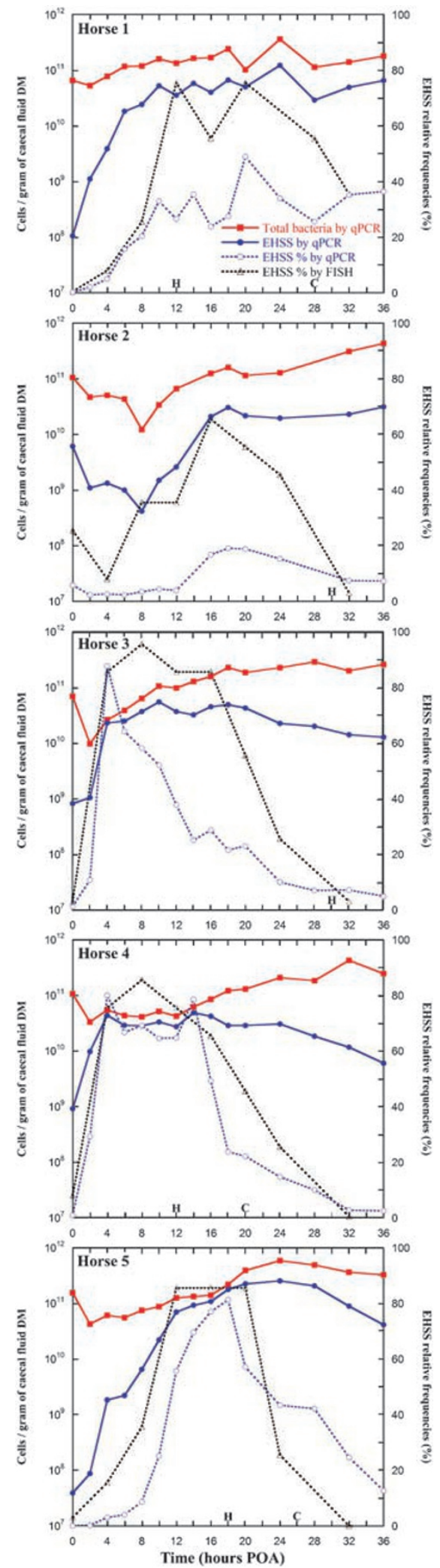

was secondary to the increases in EHSS, was less pronounced and mainly occurred subsequent to the onset of pathological changes in the foot. Furthermore, only two of the five horses harboured Enterobacteriaceae in excess of $15 \%$ by qPCR (horses 2 and 4).

Succinivibrio. S. dextrinosolvens decreased in all horses POA. As the decrease in this microorganism was less pronounced than the decrease in total bacterial numbers, the proportion of $S$. dextrinosolvens increased POA in all horses, except horse 1. The pre-induction proportion of all bacteria that were $S$. dextrinosolvens were $19.4 \%, 4.0 \%, 10.1 \%$ and $3.7 \%$ for horses $2-5$, respectively. This value peaked between 2 and $6 \mathrm{~h}$ POA, ranging between $8.3 \%$ and $40.7 \%$ and decreased to below pre-induction levels by $8-10 \mathrm{~h}$ POA in horses $3-5$ and by $16 \mathrm{~h}$ POA for horse $2 . S$. dextrinosolvens in horse 1 was $<1 \%$ of the total bacteria at all time points.

Anaerovibrio. A. lipolyticus (Tajima et al., 2001) never exceeded $0.06 \%$ of the total bacterial population by qPCR in any horse, at any time point. However, the broadened Anaerovibrio assay developed in this study determined that these bacteria were in excess of $20 \%$ in all horses. Pre-induction, Anaerovibrio comprised between $3.9 \%$ and $12.4 \%$ of total bacteria. They increased POA, however, the degree by which they increased varied markedly between horses. Between 4 and $10 \mathrm{~h}$ POA these microorganisms comprised $56.2 \%$ (6 h POA), $>90 \%$ (10h POA), 32.2\% (4h POA), 23.1\% (6h POA) and $61.5 \%$ ( $8 \mathrm{~h}$ POA) of the total bacterial population in horses $1-5$, respectively. They decreased rapidly in all horses to be at or close to their pre-induction values within $2-12 \mathrm{~h}$ of their highest values.

Fluorescence in situ hybridization

Succinivibrio. All FISH data are supplied in Supplementary Table 1. Prior to laminitis induction Succ654-hybridizing bacteria comprised $0 \%, 31-40 \%$, $6-10 \%, 21-30 \%$ and $11-20 \%$ of all bacteria in horses $1-5$, respectively. In horses $2-5$ they were $<1 \%$ by $4 \mathrm{~h}$ POA and remained at $<1 \%$ or lower for all time points except $6 \mathrm{~h}$ POA for horses 2 and 5 (both 1-5\%) and 12 and $16 \mathrm{~h}$ POA for horse $2(21-30 \%)$. These bacteria were only observed in the $8 \mathrm{~h}$ POA for horse 1

Figure 2 Caecal fluid quantitative real-time PCR (qPCR) results for total bacteria and equine hindgut streptococcal species (EHSS; left $y$ axis) and relative frequencies for Sb127-hybridizing microorganisms by fluorescence in situ hybridization (FISH) and EHSS by qPCR (right $y$ axis) for horses 1-5 (top to bottom). The time points at which histological $(\mathrm{H})$ and clinical $(\mathrm{C})$ signs of laminitis were initially observed are indicated above the $x$ axis. Note: horses 2 and 3 were initially observed to exhibit clinical signs of laminitis at 38 and $43 \mathrm{~h}$ post-oligofructose administration (POA), respectively. 
at fewer than one microorganism per microscope field (occasional).

Anaerovibrio. The Anaerovibrio-targeting FISH probe, Ana1141, hybridized to the large, curved Gram-negative rod previously described to increase in relative abundance in both caecal fluid and faeces early in the course of oligofructose-induced equine laminitis (Milinovich et al., 2007). The proportion of bacteria targeted by Ana1141 increased POA in all horses, except horse 4 and mirrored the results of the Anaerovibrio qPCR assay, albeit, at slightly lower values. Prior to laminitis induction Ana1141-hybridizing bacteria comprised $6-10 \%, 31-40 \%, 1-5 \%$, $11-20 \%$ and $1-5 \%$ of all bacteria in horses $1-5$, respectively. For horses 1-5, respectively, Ana1141hybridizing bacteria peaked at $41-50 \%$ (4h POA), 81-90\% (12 h POA), 6-10\% (4 h POA), 11-20\% (0 h POA) and $31-40 \%$ (8h POA). Ana1141-hybridizing bacteria decreased to $5 \%$ of the total bacterial cell numbers by $20,32,8,16$ and $20 \mathrm{~h}$ POA for horses $1-5$, respectively, and remained at these levels for the remaining times except for 32 and $36 \mathrm{~h}$ POA from horse 5 (6-10\%).

Lactate, volatile fatty acid and fructo-oligosaccharide analyses

Caecal fluid sucrose and all fructo-oligosaccharides monitored (DP3-7) by HPLC were detected at increased concentrations, in all horses, by $2 \mathrm{~h}$ POA (Figure 3). They declined to non-detectable concentrations by $20 \mathrm{~h}$ POA in horse 1 and $24 \mathrm{~h}$ POA in the remaining four horses. As with the other carbohydrates monitored, caecal fluid fructose concentrations increased within $2 \mathrm{~h}$ of induction in four of the five horses. Caecal fluid fructose concentration initially decreased POA in horse 3; however, the caecal fluid fructose concentrations for this horse, and for horse 1, were initially elevated compared with the other three horses (Figure 3). Fructose concentration decreased to, or close to, non-detectable concentrations in all horses by the final time point at $36 \mathrm{~h}$ POA.

Caecal fluid lactate and VFA concentrations are displayed in Figure 4. Caecal lactate concentrations immediately increased in all horses except horse 3, which decreased slightly before increasing by $4 \mathrm{~h}$ POA. The increase in lactate concentrations occurred concurrently with a decrease in VFAs. VFA concentrations typically increased by the final time

Figure 3 Caecal fluid fructose (right $y$ axis), sucrose (left $y$ axis) and fructo-oligosaccharides, with degrees of polymerization (DP) ranging from 3 to 7 , (left $y$ axis) concentrations for horses 1-5 (top to bottom). The time points at which histological $(\mathrm{H})$ and clinical (C) signs of laminitis were initially observed are indicated above the $x$ axis. Note: horses 2 and 3 were initially observed to exhibit clinical signs of laminitis at 38 and $43 \mathrm{~h}$ post-oligofructose administration (POA), respectively. point, $36 \mathrm{~h}$ POA. A large, transient increase in acetate, propionate and n-butyrate concentrations was observed at $24 \mathrm{~h}$ POA in horse 5.
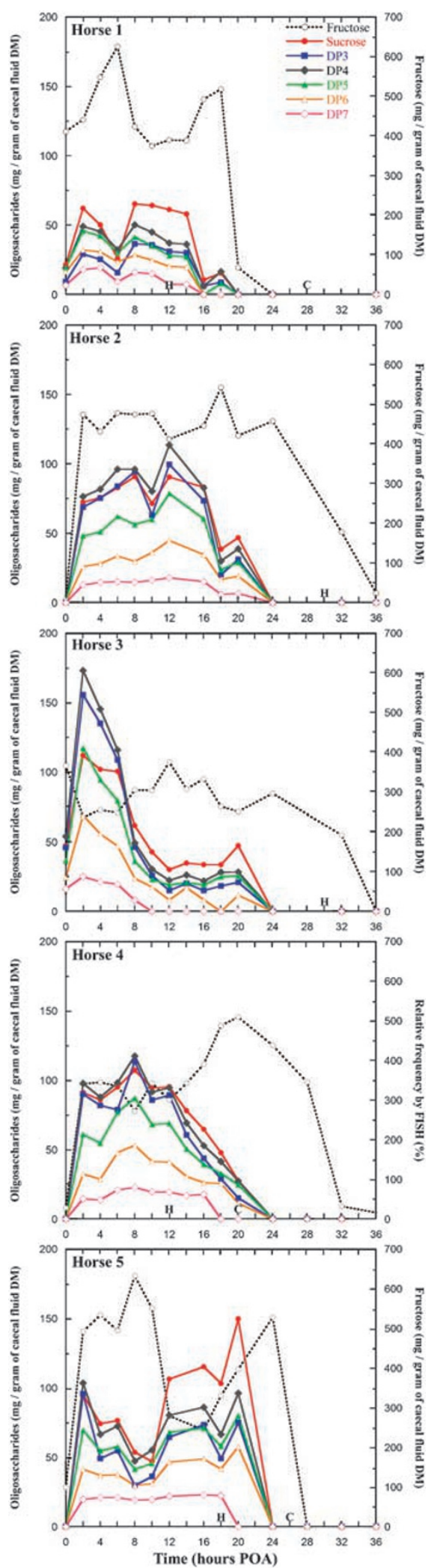

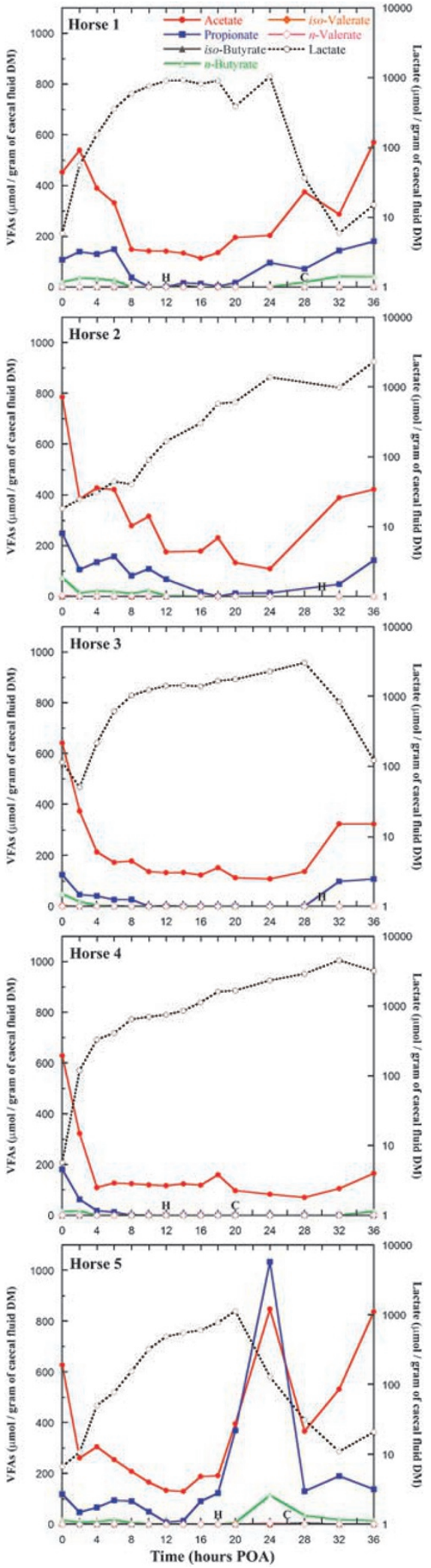

Figure 4 Caecal fluid volatile fatty acid (left $y$ axis) and lactate (right $y$ axis) concentrations for horses 1-5 (top to bottom). The time points at which histological $(\mathrm{H})$ and clinical $(\mathrm{C})$ signs of laminitis were initially observed are indicated above the $x$ axis. Note: horses 2 and 3 were initially observed to exhibit clinical signs of laminitis at 38 and $43 \mathrm{~h}$ post-oligofructose administration (POA), respectively.

\section{Discussion}

Horses are hindgut fermenters and derive $60-70 \%$ of their energy from VFAs, produced through microbial fermentation of soluble sugars and structural carbohydrates within the hindgut, which are absorbed across the epithelia of the large intestine (Daly et al., 2001). Thus, VFA concentrations can be used as indicators of intestinal health in the horse (Berg et al., 2005). Oligofructose, administered to horses at a dose rate reflecting a theoretical maximal daily consumption from temperate grasses growing under exceptional climatic conditions for fructan production $\left(10 \mathrm{~g} \mathrm{~kg}^{-1}\right.$ body weight; Longland and Byrd, 2006; van Eps and Pollitt, 2006), reached the caecum within $2 \mathrm{~h}$, in all horses (Figure 3). Microbial oligofructose fermentation resulted in a marked decrease in caecal VFA concentrations, an increase in caecal lactate concentrations and a decrease in caecal pH (Milinovich et al., 2007). These conditions are known to have numerous detrimental effects in the horse including decreased cellulolytic and hemicellulolytic bacterial cell numbers, decreased fibre digestion rates and inhibition of VFA production and absorption (Hussein et al., 2004). Caecal oligofructose fermentation generated a distinct reduction in bacterial diversity, particularly in organisms represented by amplicons that ran towards the bottom of the DGGE gels, immediately POA (Figure 1, Supplementary Figures 1-5) and there was an initial decrease in total bacterial cell numbers by qPCR in all horses (Figure 2).

Previous culture-based studies (Milinovich et al., 2006, 2007) identified EHSS as the most probable aetiological agent of equine laminitis, resulting from alimentary carbohydrate overload, a significant cause of laminitis ( $>50 \%$ of cases; USDA, 2000). Administration of oligofructose resulted in a marked proliferation of EHSS, resulting in increased caecal fluid lactate concentrations (Figure 4) and a concurrent decrease in caecal $\mathrm{pH}$ (Milinovich et al., 2007). In the present study, DGGE and qPCR clearly and consistently demonstrated that EHSS became established as the predominant bacteria in the equine hindgut prior to the onset of laminitis. Culture-based studies indicated S. lutetiensis to be the most dominant oligofructose-utilizing organism culturable from the equine hindgut prior to the onset of laminitis (Milinovich et al., 2006). In our study, 11 of 12 streptococcal 16S rRNA gene clones had the closest identity to $S$. lutetiensis. Thus $S$. lutetiensis is both the predominant bacterium and the predominant oligofructose-utilizing microorganism present in the equine hindgut prior to the onset of laminitis. Histological signs of laminitis were observed in all horses before lactate concentrations returned to pre-induction values; however, whether the large quantities of lactate produced from oligofructose fermentation are directly involved in the development of laminitis remains to be investigated. Regardless, these results confirm that the 
detrimental effects on hindgut function discussed above are a direct consequence of proliferation of S. lutetiensis.

Both qPCR and FISH (with probe Sb127) were used to quantify the proportion of total bacteria that were EHSS in the equine caecum during oligofructose-induced laminitis. Our qPCR targets the 16S rRNA genes in genomic DNA extracts from caecal fluid samples and FISH targets the 16S rRNA in intact whole cells. EHSS qPCR results correlated with FISH relative frequencies throughout the laminitis process (Figure 2). EHSS cell numbers determined by qPCR, however, did not correlate with the FISH results. Results for times up to $16 \mathrm{~h}$ POA showed good congruence between qPCR and FISH, demonstrating that these microorganisms increased sharply and then reached a plateau. However, there was no correlation between qPCR and FISH quantification after $16 \mathrm{~h}$ POA. FISH demonstrated a rapid decline in EHSS numbers whereas qPCR quantifications remained at the plateau level until $36 \mathrm{~h}$ POA. FISH is reported to be sensitive to $10^{6}$ bacterial cells per gram of faeces (Zoetendal et al., 2004). At $32 \mathrm{~h}$ POA qPCR detected between $2.97 \times 10^{8}$ and $2.95 \times 10^{9}$ EHSS cells per gram of caecal fluid (values not adjusted for dry matter content) in horses 2-5, values approaching 3000 times the lower detection limits of FISH. Despite qPCR indicating that EHSS were well above the lower detection limits, only a few cells were observed by FISH. One explanation for the lack of congruence between qPCR and FISH may be that the EHSS are being lysed, releasing genomic DNA and other cellular constituents into the caecum. This hypothesis could explain the discrepancy between the qPCR and FISH results. That is, intact cells (observable by FISH) decline, but sufficient genomic DNA fragments remain in the caecum to be detected by qPCR. The lysis of an organism, particularly one in such high numbers as the EHSS in the equine hindgut during laminitis induction, could expose the milieu to several potentially toxic cellular constituents. If EHSS are proven to undergo lysis, liberated cellular components may be responsible for initiating laminitis.

As little as $30 \%$ of the equine caecal microbiota are culturable (Mackie and Wilkins, 1988) and while culture-based studies have greatly increased our understanding of the laminitis process, the techniques are prone to biases. This is highlighted by the demonstration, by DGGE, in this study of two previously unidentified groups, Anaerovibrio-like bacteria and Succinivibrio spp., shown to comprise a high proportion of total bacteria in the equine caecum prior to the onset of laminitis or to proliferate immediately POA. DGGE also demonstrated a clear and consistent shift in E. coli subpopulations during laminitis, a phenomenon that has not been reported in any previous studies. These results highlight the effectiveness of DGGE in monitoring changes, or distinguishing differences, in highly complex microbial communities. The DGGE results of this study corroborate results from FISH (Milinovich et al., 2007), which demonstrated lactobacilli to comprise a small proportion of total bacteria in the caecum prior to the development of histological evidence of laminitis. Only two lactobacilli species, $L$. equi and $L$. hayakitensis, were consistently observed by DGGE to inhabit the equine caecum and to proliferate over the time course.

Previous studies (Milinovich et al., 2006, 2007) showed Enterobacteriaceae to be present in low numbers prior to the onset of laminitis in the horse, and to increase throughout the laminitis process. This is corroborated by the Enterobacteriaceae qPCR results of this study. It has been reported that there may be in excess of 1000 different strains of coliforms present in the equine hindgut (Golomidova et al., 2007), demonstrating that further study, including collection and study of isolates of each of the E. coli subpopulations, demonstrated by DGGE, should be done.

We demonstrated that the A. lipolyticus qPCR assay of Tajima et al. (2001) was of limited efficacy in enumerating Anaerovibrio-like organisms in the equine hindgut during laminitis induction. Due to the proportion of Anaerovibrio-like sequences in the clone libraries, we developed a novel qPCR assay and FISH probe (Ana1141) specific for these bacteria. The novel qPCR detected cell numbers as high as $6.56 \times 10^{10}$ cells per gram of caecal fluid dry matter. Therefore the unidentified, large, curved, Gram-negative rod observed by FISH and described in a previous study (Milinovich et al., 2007) is likely not $A$. lipolyticus, but probably, an Anaerovibrio-like bacterium. The $16 \mathrm{~S}$ rRNA gene sequences obtained from clones targeted in FISH and qPCR are between $87.2 \%$ and $93.2 \%$ identical to nearest sequences, demonstrating that if the Anaerovibrio-like bacteria are homogeneous, they are likely to represent a novel genus and species. The role of these bacteria in laminitis can be definitively determined when pure cultures are available.

According to FISH with the Succ654 probe, $S$. dextrinosolvens-like bacteria were present to varying degrees in all horses prior to administration of oligofructose but declined by $4 \mathrm{~h}$ POA and remained low. qPCR substantiated this; however, based on the current data the role of $S$. dextrinosolvens-like bacteria in the laminitis development process cannot be conclusively determined.

Oligofructose is marketed as a dietary supplement with pre-biotic properties for humans and numerous species of animals, including horses. Of the limited publications on the effects of oligofructose on colonic bacterial populations in horses and other species (Beynen et al., 2002; Macfarlane et al., 2006; Milinovich et al., 2007; Respondek et al., 2008), all report a significant increase in streptococci. If EHSS are responsible for laminitis, as we suggest, the effect of dietary supplementation with oligofructose 
at pre-biotic dosage rates needs to be studied promptly.

Since the development of the first experimental model for inducing laminitis of alimentary origin (Garner et al., 1975), numerous species of bacteria have been implicated as possible aetiological agents. However, substantial evidence demonstrates EHSS to be the most likely causative agent. The establishment of this group of organisms as aetiological agent of equine laminitis cannot occur conclusively without determining the sequence of events that culminate in lamellar separation. The results of this study suggest EHSS undergo a lytic event and liberated cellular components may constitute the laminitis trigger factor.

\section{Acknowledgements}

This project was supported by the Rural Industries Research and Development Corporation (RIRDC) of Australia and the Animal Health Foundation (AHF), St Louis, Missouri, USA. We thank Graham Kerven of The University of Queensland's School of Land, Crop and Food Science for chromatography assistance, Lester Walters and the staff of Eagle Farm Equine Hospital for performing the surgery to place the caecal fistulas in the animals used in this study, Elena Constantinoiu of The University of Queensland's School of Veterinary Science for assistance in processing of samples, Lyle McMillen of the Department of Primary Industries and Fisheries' Animal Research Institute for technical assistance with qPCR and Christopher Owens for monitoring of animals and collection of samples.

\section{References}

Al Jassim RA, Scott PT, Trebbin AL, Trott DJ, Pollitt CC. (2005). The genetic diversity of lactic acid producing bacteria in the equine gastrointestinal tract. FEMS Microbiol Lett 248: 75-81.

Amann RI. (1995). Fluorescently labelled, ribosomal-RNAtargeted oligonucleotide probes in the study of microbial ecology. Mol Ecol 4: 543-553.

Bartosch S, Fite A, Macfarlane GT, McMurdo ME. (2004). Characterization of bacterial communities in feces from healthy elderly volunteers and hospitalized elderly patients by using real-time PCR and effects of antibiotic treatment on the fecal microbiota. Appl Environ Microbiol 70: 3575-3581.

Berg EL, Fu CJ, Porter JH, Kerley MS. (2005). Fructooligosaccharide supplementation in the yearling horse: effects on fecal pH, microbial content, and volatile fatty acid concentrations. J Anim Sci 83: 1549-1553.

Beynen AC, Baas JC, Hoekemeijer PE, Kappert HJ, Bakker MH, Koopman JP et al. (2002). Faecal bacterial profile, nitrogen excretion and mineral absorption in healthy dogs fed supplemental oligofructose. J Anim Physiol Anim Nutr (Berl) 86: 298-305.

Bjornsson L, Hugenholtz P, Tyson GW, Blackall LL. (2002). Filamentous Chloroflexi (green non-sulfur bacteria) are abundant in wastewater treatment processes with biological nutrient removal. Microbiology 148: 2309-2318.
Cairns AJ, Longland AC. (1998). International Research Conference on Equine Laminitis. Dodson and Horrell: Stoneliegh, Warwickshire, England, pp 1-3.

Croser EL, Pollitt CC. (2006). 52nd Annual Convention of the American Association of Equine Practitioners. American Association of Equine Practitioners: San Antonio, TX, USA, pp 542-546.

Daims H, Bruhl A, Amann R, Schleifer KH, Wagner M. (1999). The domain-specific probe EUB338 is insufficient for the detection of all bacteria: development and evaluation of a more comprehensive probe set. Syst Appl Microbiol 22: 434-444.

Daly K, Stewart CS, Flint HJ, Shirazi-Beechey SP. (2001). Bacterial diversity within the equine large intestine as revealed by molecular analysis of cloned 16S rRNA genes. FEMS Microbiol Ecol 38: 141-151.

Ewaschuk JB, Zello GA, Naylor JM, Brocks DR. (2002). Metabolic acidosis: separation methods and biological relevance of organic acids and lactic acid enantiomers. J Chromatogr B Analyt Technol Biomed Life Sci 781: 39-56.

French KR, Pollitt CC. (2004). Equine laminitis: cleavage of laminin 5 associated with basement membrane dysadhesion. Equine Vet J 36: 242-247.

Garner HE, Coffman JR, Hahn AW, Hutcheson DP, Tumbleson ME. (1975). Equine laminitis of alimentary origin: an experimental model. Am J Vet Res 36: 441-444.

Golomidova A, Kulikov E, Isaeva A, Manykin A, Letarov A. (2007). The diversity of coliphages and coliforms in horse feces reveals a complex pattern of ecological interactions. Appl Environ Microbiol 73: 5975-5981.

Hugenholtz P, Tyson GW, Blackall LL. (2002). Design and evaluation of $16 \mathrm{~S}$ rRNA-targeted oligonucleotide probes for fluorescence in situ hybridization. Methods Mol Biol 179: 29-42.

Hugenholtz P, Tyson GW, Webb RI, Wagner AM, Blackall LL. (2001). Investigation of candidate division TM7, a recently recognized major lineage of the domain bacteria with no known pure-culture representatives. Appl Environ Microbiol 67: 411-419.

Hussein HS, Vogedes LA, Fernandez GC, Frankeny RL. (2004). Effects of cereal grain supplementation on apparent digestibility of nutrients and concentrations of fermentation end-products in the feces and serum of horses consuming alfalfa cubes. J Anim Sci 82: 1986-1996.

Klieve AV, Hennessy D, Ouwerkerk D, Forster RJ, Mackie RI, Attwood GT. (2003). Establishing populations of Megasphaera elsdenii YE 34 and Butyrivibrio fibrisolvens YE 44 in the rumen of cattle fed high grain diets. J Appl Microbiol 95: 621-630.

Klieve AV, Hudman JF, Bauchop T. (1989). Inducible bacteriophages from ruminal bacteria. Appl Environ Microbiol 55: 1630-1634.

Klieve AV, O’Leary MN, McMillen L, Ouwerkerk D. (2007). Ruminococcus bromii, identification and isolation as a dominant community member in the rumen of cattle fed a barley diet. J Appl Microbiol 103: 2065-2073.

Kocherginskaya SA, Cann IKO, Mackie RI. (2005). Denaturing gradient gel electrophoresis. In: Makkar HPS, Mcsweeney CS (eds). Methods in Gut Microbial Ecology for Ruminants. International Atomic Energy Agency, Springer Academic Press: Dordrecht, Netherlands, pp 119-128.

Lane DJ. (1991). 16S/23S rRNA sequencing. In: Stackebrandt E, Goodfellow M (eds). Nucleic Acid 
Techniques in Bacterial Systematics. Wiley: New York, pp 115-175.

Longland AC, Byrd BM. (2006). Pasture nonstructural carbohydrates and equine laminitis. J Nutr 136: 2099S-2102S.

Macfarlane S, Macfarlane GT, Cummings JH. (2006). Review article: prebiotics in the gastrointestinal tract. Aliment Pharmacol Ther 24: 701-714.

Mackie RI, Wilkins CA. (1988). Enumeration of anaerobic bacterial microflora of the equine gastrointestinal tract. Appl Environ Microbiol 54: 2155-2160.

Milinovich GJ, Burrell PC, Pollitt CC, Bouvet A, Trott DJ. (2008). Streptococcus henryi sp. nov. and Streptococcus caballi sp. nov.: two novel streptococci isolated from the hindgut of horses with oligofructoseinduced laminitis. Int $J$ Syst Evol Microbiol 58: 262-266.

Milinovich GJ, Trott DJ, Burrell PC, Croser EL, Al Jassim RA, Morton JM et al. (2007). Fluorescence in situ hybridization analysis of hindgut bacteria associated with the development of equine laminitis. Environ Microbiol 9: 2090-2100.

Milinovich GJ, Trott DJ, Burrell PC, van Eps AW, Thoefner MB, Blackall LL et al. (2006). Changes in equine hindgut bacterial populations during oligofructose-induced laminitis. Environ Microbiol 8: 885-898.

Morita H, Shiratori C, Murakami M, Takami H, Kato Y, Endo A et al. (2007). Lactobacillus hayakitensis sp. nov., isolated from intestines of healthy thoroughbreds. Int J Syst Evol Microbiol 57: 2836-2839.

Morotomi M, Yuki N, Kado Y, Kushiro A, Shimazaki T, Watanabe K et al. (2002). Lactobacillus equi sp. nov., a predominant intestinal Lactobacillus species of the horse isolated from faeces of healthy horses. Int J Syst Evol Microbiol 52: 211-214.

Muyzer G, de Waal EC, Uitterlinden AG. (1993). Profiling of complex microbial populations by denaturing gradient gel electrophoresis analysis of polymerase chain reaction-amplified genes coding for $16 \mathrm{~S}$ rRNA. Appl Environ Microbiol 59: 695-700.

Nadkarni MA, Martin FE, Jacques NA, Hunter N. (2002). Determination of bacterial load by real-time PCR using a broad-range (universal) probe and primers set. Microbiology 148: 257-266.

Nilsson U, Oste R, Jagerstad M, Birkhed D. (1988). Cereal fructans: in vitro and in vivo studies on availability in rats and humans. J Nutr 118: 1325-1330.
Ouwerkerk D, Klieve AV. (2001). Bacterial diversity within feedlot manure. Anaerobe 7: 59-66.

Ouwerkerk D, Klieve AV, Forster RJ. (2002). Enumeration of Megasphaera elsdenii in rumen contents by realtime Taq nuclease assay. J Appl Microbiol 92: 753-758.

Pollitt CC. (1999). 45th Annual convention of the American Association of Equine Practitioners. American Association of Equine Practitioners: Albuquerque, New Mexico, USA, pp 188-192.

Respondek F, Goachet AG, Julliand V. (2008). Effects of dietary short-chain fructooligosaccharides on the intestinal microflora of horses subjected to a sudden change in diet. J Anim Sci 86: 316-323.

Roberfroid MB, Delzenne NM. (1998). Dietary fructans. Annu Rev Nutr 18: 117-143.

Stahl DA, Amann RI. (1991). Development and application of nucleic acid probes. In: Stackebrandt E and Goodfellow M (eds). Nucleic Acid Techniques in Bacterial Systematics. Academic Press: Chicester, pp 205-248.

Stevenson DM, Weimer PJ. (2007). Dominance of Prevotella and low abundance of classical ruminal bacterial species in the bovine rumen revealed by relative quantification real-time PCR. Appl Microbiol Biotechnol 75: 165-174.

Tajima K, Aminov RI, Nagamine T, Matsui H, Nakamura M, Benno Y. (2001). Diet-dependent shifts in the bacterial population of the rumen revealed with real-time PCR. Appl Environ Microbiol 67: 2766-2774.

USDA (2000). Lameness and Laminitis in US Horses. USDA:APHIS:VS, CEAH, National Animal Health Monitoring System: Fort Collins, Colorado, USA.

van Eps AW, Pollitt CC. (2004). Equine laminitis: cryotherapy reduces the severity of the acute lesion. Equine Vet J 36: 255-260.

van Eps AW, Pollitt CC. (2006). Equine laminitis induced with oligofructose. Equine Vet J 38: 203-208.

$\mathrm{Yu}$ Z, Forster RJ. (2005). Nucleic acid extraction, oligonucleotide probes and PCR methods. In: Makkar HPS and Mcsweeney CS (eds). Methods in Gut Microbial Ecology for Ruminants. International Atomic Energy Agency, Springer Academic Press: Dortrecht, the Netherlands, pp 81-104.

Zoetendal EG, Cheng B, Koike S, Mackie RI. (2004). Molecular microbial ecology of the gastrointestinal tract: from phylogeny to function. Curr Issues Intest Microbiol 5: 31-47.

Supplementary Information accompanies the paper on The ISME Journal website (http://www.nature.com/ismej) 